\title{
Assessing fish metrics and biotic indices in a Mediterranean stream: effects of uncertain native status of fish
}

\author{
L. Benejam - E. Aparicio - M. J. Vargas • \\ A. Vila-Gispert · E. García-Berthou
}

Received: 29 June 2007 / Revised: 11 December 2007 / Accepted: 27 December 2007 / Published online: 23 January 2008

(C) Springer Science+Business Media B.V. 2008

\begin{abstract}
Implementation of the Water Framework Directive requires tools for measuring and monitoring the ecological status of aquatic ecosystems. Several indices are in use in the Iberian Peninsula, although there has been little comparison among them. We sampled the fish assemblage and limnological features of the Tordera stream (NE Spain) quarterly from September 2001 to May 2003 to evaluate the usefulness of several fish metrics and to compare habitat quality and biotic indices currently in use. Data for eight biotic and abiotic indices for this and three other Catalan river basins were also compiled in order to analyse the relationships among indices. In the Tordera stream, fish abundance and richness increased with stream order except in the last sampling site that had the lowest fish abundance owing to the effects of drought and water abstraction. Although most indices were positively correlated, some displayed low or null correlations particularly for the Tordera basin which is more affected by water abstraction and less by pollution; a commonly used physico-chemical index (ISQA) was the least
\end{abstract}

Handling editor: K. Martens

L. Benejam - E. Aparicio - M. J. Vargas .

A. Vila-Gispert · E. García-Berthou $(\square)$

Institute of Aquatic Ecology, University of Girona, 17071

Girona, Catalonia, Spain

e-mail: emili.garcia@udg.edu

URL: http://ciencies.udg.edu/w3/EGarcia/ correlated. In a regional fish index (IBICAT) under development, the brown trout (Salmo trutta) has been previously considered as introduced in the Tordera basin. Here, we report an old published record that demonstrates that trout was present before 1845 and we argue that its status should be considered as uncertain given the current information available. Whether brown trout is treated as native or introduced to this river basin has profound effects on the results of fish metrics because of its dominance in the upper reaches. We briefly discuss the role of introduced species, particularly in headwater streams, in the development of fish indices. Our study exemplifies the need for careful, basin-specific assessment of native/introduced status in the development of fish metrics.

Keywords Water Framework Directive .

Biotic integrity · Introduced species ·

Brown trout $\cdot$ Salmo trutta

\section{Introduction}

In December 2000, the European Union enacted a new and ambitious water policy, the Water Framework Directive (WFD). According to the WFD, Member States are required to protect and restore all aquatic ecosystems with the aim of achieving good ecological status by 2015. The WFD also requires Member States to measure the ecological status of 
aquatic ecosystems by assessing their hydromorphological, chemical and biological characteristics. In the WFD, ecological status is defined as "an expression of the quality of the structure and functioning of aquatic ecosystems associated with surface waters" and for biological quality elements is mainly measured as changes in the composition and abundance of different taxonomic groups. For rivers, three biological elements are required for the classification of ecological status: aquatic flora, benthic invertebrates and fish.

In the Iberian Peninsula, and for its Mediterranean streams in particular, several biotic and abiotic indices have been extensively applied for water quality and ecological monitoring: the Simplified valuation of water quality, ISQA (Queralt, 1982); the riparian vegetation quality index, QBR (Munné et al., 2003); the habitat quality index, IH (Pardo et al., 2002); an index based on diatoms, IPS (Cemagref, 1982; ACA, 2003); and several indices based on macroinvertebrates, such as IBMWP and IASPT (Alba-Tercedor \& Sánchez-Ortega, 1988; Alba-Tercedor et al., 2002) and others specific for Catalan rivers and streams, FBILL (Prat et al., 1999, 2000) and BMWPC (Benito \& Puig, 1999). ISQA and BMWPC indices have been used routinely by the Catalan Water Agency, Government of Catalonia for water quality monitoring (see http:// www.gencat.net/aca/), whereas FBILL, QBR, IBMWP, IH, IASPT and IPS are used by the Barcelona Provincial Council (see http://www.diba.cat/mediambient/ ecostrimed.asp).

In contrast, biotic indices based on stream fish assemblages are much less developed in Europe and particularly the Iberian Peninsula. Since the first proposal of the Index of Biotic Integrity, IBI (Karr, 1981; Karr et al., 1986), fish have been used as ecological indicators for about 20 years, but mostly in North America (Hughes \& Oberdorff, 1999). Within Europe, Oberdorff et al. (2002) pioneered the development of a fish-based index (FBI) in France and Pont et al. (2006) proposed a European fish assemblage index that is under further elaboration. However, this general index does not work well in Mediterranean rivers and streams because of low fish richness, high degree of endemicity and strong spatial variation in fish faunas (Ferreira et al., unpublished manuscript), as a result of evolutionary history and the lower and irregular availability of fresh water in Mediterranean ecosystems (Doadrio et al., 1991;
Reyjol et al., 2007). For this reason, specific fish metrics need to be validated and adapted to the Iberian Peninsula. Sostoa et al. (2003) distinguished five types among Catalan rivers and for each type demonstrated the relationship of 1-3 fish metrics with human disturbances, tentatively suggesting an index of biotic integrity (IBICAT). We are not aware of other fish indices specific to the Iberian Peninsula. Identifying fish metrics that respond to disturbances in Mediterranean-type streams is thus an urgent need, particularly in the context of the WFD.

There have been a few comparative studies of biotic indices in the Iberian Peninsula and mostly only between pairs of indices (Prat et al., 1986; Sabater, 2000; Pardo et al., 2002; Bonada et al., 2004; Damásio et al., 2007). We studied the fish assemblage of a Mediterranean river basin (Tordera) during two years to evaluate the usefulness of several fish metrics in relation to several habitat quality and biotic indices. In addition, we analysed the relationship among several water quality, hydromorphological and biotic indices used in Catalonia across four river basins.

\section{Methods}

Field study

The Tordera stream (Catalonia, NE Spain) rises in the Montseny mountains, covers a drainage area of approximately $895 \mathrm{~km}^{2}$, and is fed by sudden torrential discharges. It has highest flow in spring and a typical Mediterranean severe drought in summer. There are no dams along the stream, but river flow is heavily reduced owing to water abstraction for irrigation, human consumption and industry; this intensifies the drought periods. Predominant land use in the river basin is row-crop agriculture and residential. The water quality of the river is being monitored (see references below) and some further data on macroinvertebrates (Ortiz et al., 2006) and fish (Aparicio et al., 2000; Sostoa et al., 2003) are available, particularly in one of its tributaries, Fuirosos stream (see Romaní et al., 2004; Domènech et al., 2006; and references therein).

From September 2001 to May 2003, fish and abiotic variables were measured quarterly at seven sites along the stream (Fig. 1, Table 1). The summer of 2001 represented a very dry year in which more 


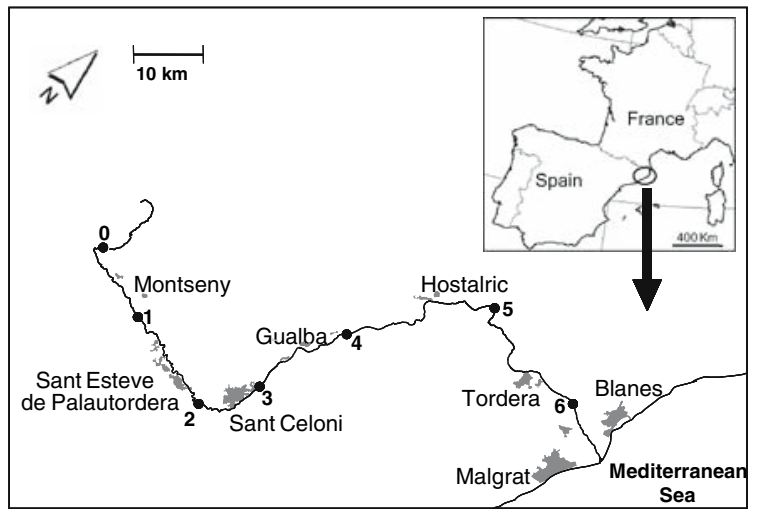

Fig. 1 Location of sampling sites along the Tordera stream: 0, Llavina; 1, Sant Esteve; 2, Santa Maria; 3, Sant Celoni; 4, Can Perxistó; 5, Estació d'Aforament; 6, Tordera. See Table 1 for further information

than $50 \%$ of the main stream course dried up, mainly from the middle to lower reaches. In each sampling date, the following variables were measured: altitude $(\mathrm{m})$, stretch wetted width (m), percentage of substrate composition (stones, rocks and silt); percentage of refuges, pools and riffles, and percentage of vegetation (trees, bushes and hydrophytes). Other variables such as ammonium, nitrite, nitrate, phosphate, sulphate and chloride concentrations, water flow $\left(\mathrm{m}^{3} / \mathrm{s}\right)$, oxygen saturation, $\mathrm{pH}$, water temperature $\left({ }^{\circ} \mathrm{C}\right)$ and conductivity $(\mu \mathrm{S} / \mathrm{cm})$ were simultaneously obtained by other monitoring teams (Prat et al., 2002; Boada et al., 2003; http://www.gencat.net/aca). Selected habitat and limnological features of sampling sites are summarized in Table 1.

Fish were sampled by electrofishing $100 \mathrm{~m}$ stretches of the seven sampling sites. In all sampling sites, electrofishing surveys employed the following procedure: stretches were blocked off with barrier nets and two successive electrofishing passes (200$350 \mathrm{~V}, 2-3$ A fully rectified triphasic DC) were performed to estimate fish density using the removal method (Seber, 1982). All fish were anesthetised with tricaine (MS-222), identified, counted, measured (fork length, in $\mathrm{mm}$ ) and released after the twopasses.

Fish metrics and biotic indices

For each sampling site of the Tordera stream we computed several conventional fish metrics, such as

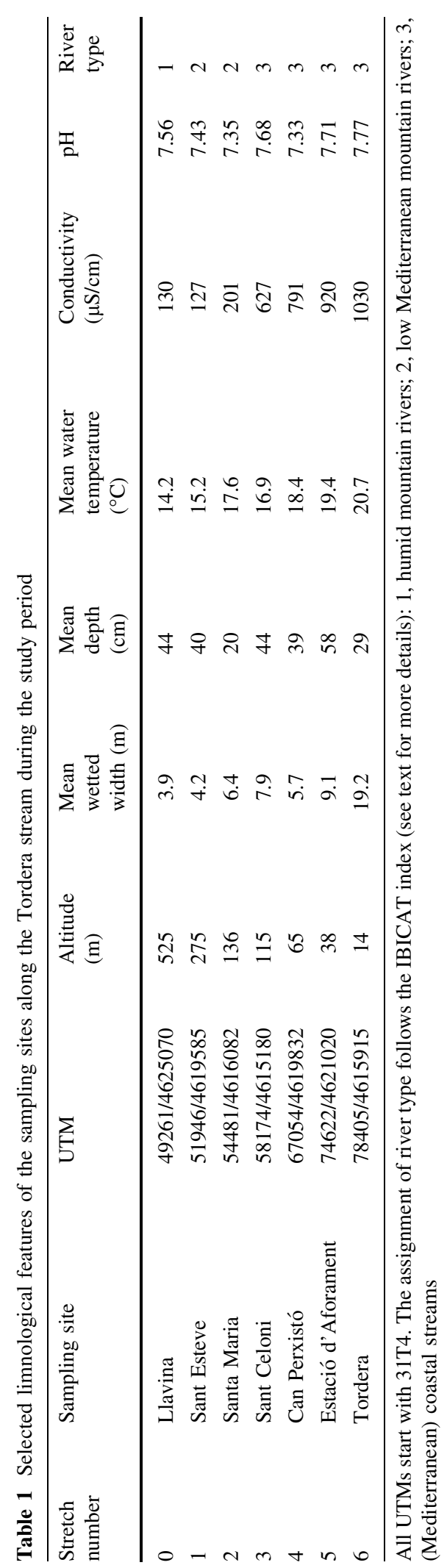


species richness, total density (fish/ha), percentage of fish with anomalies (external diseases and malformations), percentage of native fish species and percentage of native individuals. Percentage of native fish species and percentage of native fish individuals were calculated both considering brown trout (Salmo trutta L.) as a native and introduced, because brown trout status in Tordera basin is uncertain (see Discussion).

Water quality and ecological indices such as ISQA (Queralt, 1982), QBR (Munné et al., 2003), IPS (Cemagref, 1982) and FBILL (Prat et al., 1999, 2000) were compared with the fish metrics. The ISQA (Simplified valuation of water quality) is a water quality index based on five parameters: water temperature; dissolved organic matter; conductivity; oxygen availability and chemical oxygen demand. The QBR (Riparian Habitat Quality Index) is a habitat quality index that accounts for riparian cover percentage, cover structure, cover quality and naturalness of the river channel. The IPS (Specific Pollution Sensitivity index) is the biotic index based on diatoms that works better in Catalan rivers (Damásio et al., 2007), whereas FBILL (Family Biotic Index for Llobregat river) is a biotic index based on benthic macroinvertebrates. Data from all these indices came from the Catalan Water Agency (data can be downloaded at http://www.gencat.net/aca/en//aiguamedi/ rius/inici.jsp), Prat et al. (2002), and Boada et al. (2003).

To further compare the information provided by the different water quality, habitat and biotic indices, we also used data from three other Catalan river basins (Besós, Foix and Llobregat) (Prat et al., 2002; Boada et al., 2003; http://www.gencat.net/aca/). The indices analysed were the aforementioned ISQA, QBR, FBILL and the following five: IH (Fluvial Habitat Index, Pardo et al., 2002), which is a rapid bio-assessment measure of habitat diversity; IBMWP (Iberian Biological Monitoring Working Party, AlbaTercedor et al., 2002), based on benthic macroinvertebrates and adapted to Iberian rivers and streams; BMWPC (Biological Monitoring Working Party for Catalonia, Benito \& Puig, 1999), also based on benthic macroinvertebrates but adapted to Catalan rivers and streams; IASPT (Iberian Average Score per Taxon, Alba-Tercedor \& Sánchez-Ortega, 1988; Alba-Tercedor et al., 2002), which measures the mean tolerance level of the macroinvertebrate community and IBICAT (Sostoa et al., 2003). IBMWP,
BMWPC, FBILL, IASPT, and IBICAT are thus biological quality indices, ISQA is an abiotic index that measures physicochemical properties and QBR and IH are hydromorphological indices.

IBICAT distinguishes five river types in Catalonia: high mountain rivers, Ebro main watercourses, humid mountain rivers, low Mediterranean mountain rivers and (Mediterranean) littoral streams (Sostoa et al., 2003; ACA, 2006); only the three latter are present in Tordera river basin. IBICAT considers the following metrics: percentage of native species and percentage of intolerant species for the humid mountain river type; number of native species, number of insectivorous native species and density of intolerant native species for the low Mediterranean mountain river type; and percentage of native species, percentage of insectivorous species (including introduced species) and percentage of native species referred to the historical ones for the littoral stream type. All of these metrics score from 1 (poor) to 5 (good) ( Sostoa et al., 2003; ACA, 2006) and were averaged for each sampling site.

\section{Statistical analyses}

Principal component analyses (PCA) were applied to habitat and limnological variables, and to biotic indices and fish metrics to describe the main sources of variation and relationships. To improve linearity, nutrient concentrations and water flow were logtransformed $\left(\log _{10}\right)$. To reduce problems with compositional data, some categories (e.g., rocks and stones) were pooled and redundant variables (adding $100 \%$ ) were excluded. Kaiser-Meyer-Olkin's measure of sampling adequacy (KMO) was used to assess the usefulness of a PCA. KMO ranges from 0 to 1 and should be well above 0.5 if variables are very interdependent and a PCA is useful. Bivariate relationships were analysed using Spearman's correlation coefficient.

Correspondence analysis (CA) was used to analyse the main patterns of variation in fish species composition. For community ecological data, CA generally performs better than principal component analysis, owing to unimodal response of species abundance to environmental gradients (ter Braak, 1987).

The relationship of IBMWP (a biotic index based on macroinvertebrates) with ISQA (water quality 
index) and IBICAT (a fish index) by river or stream affiliations were tested by linear regression. All statistical analyses were performed with SPSS 12.

\section{Results}

Water quality in Tordera stream

Correlations among all pairwise combinations of habitat and limnological variables are given in Table 2. Most of the variables were significantly correlated and KMO $(=0.57)$ indicated the usefulness of a PCA, which explained $47 \%$ of the variation with two axes (Fig. 2). As also seen with the factor loadings, the highest correlations were found among altitude, percentage of bushes and trees, percentage of stones and rocks, percentage of riffles and oxygen saturation which were positively intercorrelated and negatively related to stretch width, percentage of hydrophytes and bare ground, chloride concentration, and temperature. Hence, the first PCA axis was related to the variation of sampling sites from upstream to downstream (Fig. 2), corresponding to river altitudinal zonation but also increased pollution downstream (as shown by chloride concentration). Percentage of bushes and trees, percentage of stones and rocks, percentage of riffles and oxygen saturation increased with altitude along the course of the Tordera stream, whereas stretch width, percentage of hydrophytes and ground, chloride concentration, and temperature decreased.

The second dimension of the PCA corresponded to seasonal variation. In summer, the percentage of pools and silt were highest, whereas $\mathrm{pH}$ and nitrite concentration were lowest; in spring the situation was reversed, while autumn had intermediate scores on the second dimension (Fig. 2).

Fish assemblage in Tordera stream

Eleven species captured in the study area comprised six native to Catalonia and five exotics (Table 3 ). The most abundant species in the Tordera stream, such as the Mediterranean barbel (Barbus meridionalis Risso), chub (Squalius cephalus L.) and eel (Anguilla anguilla L.), were native. For the correspondence analysis, the first two dimensions were considered because they explained $42 \%$ and $21 \%$ of the variation, respectively. The first CA dimension differentiated the site at highest altitude dominated by salmonid species (Salmo trutta and Oncorhynchus mykiss Walbaum) from the rest, usually without salmonids (Fig. 3). The second dimension displayed further altitudinal variation in species composition for the sites without salmonids: Mediterranean barbel and chub dominated all sampling sites, whereas eel and some mullets (Mugilidae) were mainly abundant in the last two downstream sampling sites (Fig. 3). In addition, exotic species such as common carp (Cyprinus carpio L.), mosquitofish (Gambusia holbrooki Agassiz), largemouth bass (Micropterus salmoides Lacépède) and pumpkinseed (Lepomis gibbosus L.) were also found in downstream sampling sites (Table 3). Fish abundance increased with stream order except in the last downstream sampling site, which had the lowest fish abundance (Fig. 3). Eel were mainly concentrated in Estació d'Aforament (site 5) owing to the presence of a man-made physical barrier that restricted upstream migration.

Fish metrics and biotic indices

Since most of the fish metrics were significantly correlated (Table 4), a PCA analysis gave a synoptic view that accounted for most of the variation in fish metrics $(\mathrm{KMO}=0.50)$. PCA explained $64 \%$ of the variation with two axes $(24.1 \%$ and $17.9 \%$, respectively) (Fig. 4). If we consider brown trout as native, percentage of native fish species and percentage of native fish individuals were negatively correlated with all richness variables and positively correlated with biotic indices, particularly QBR (Table 4, Fig. 4). In contrast, with the brown trout considered as introduced, percentage of native fish species and percentage of native fish individuals were not significantly correlated with any of the richness variables and were negatively correlated with most of the biotic indices (Table 4, Fig. 4). Other fish metrics, such as percentage of fish with anomalies were significantly correlated with native richness (Table 4).

Similarly, a more comprehensive dataset with three more Catalan river basins showed that biotic indices were generally positively correlated (Table 5), although some correlations with IBICAT were not significant. Accordingly, two axes of a PCA 


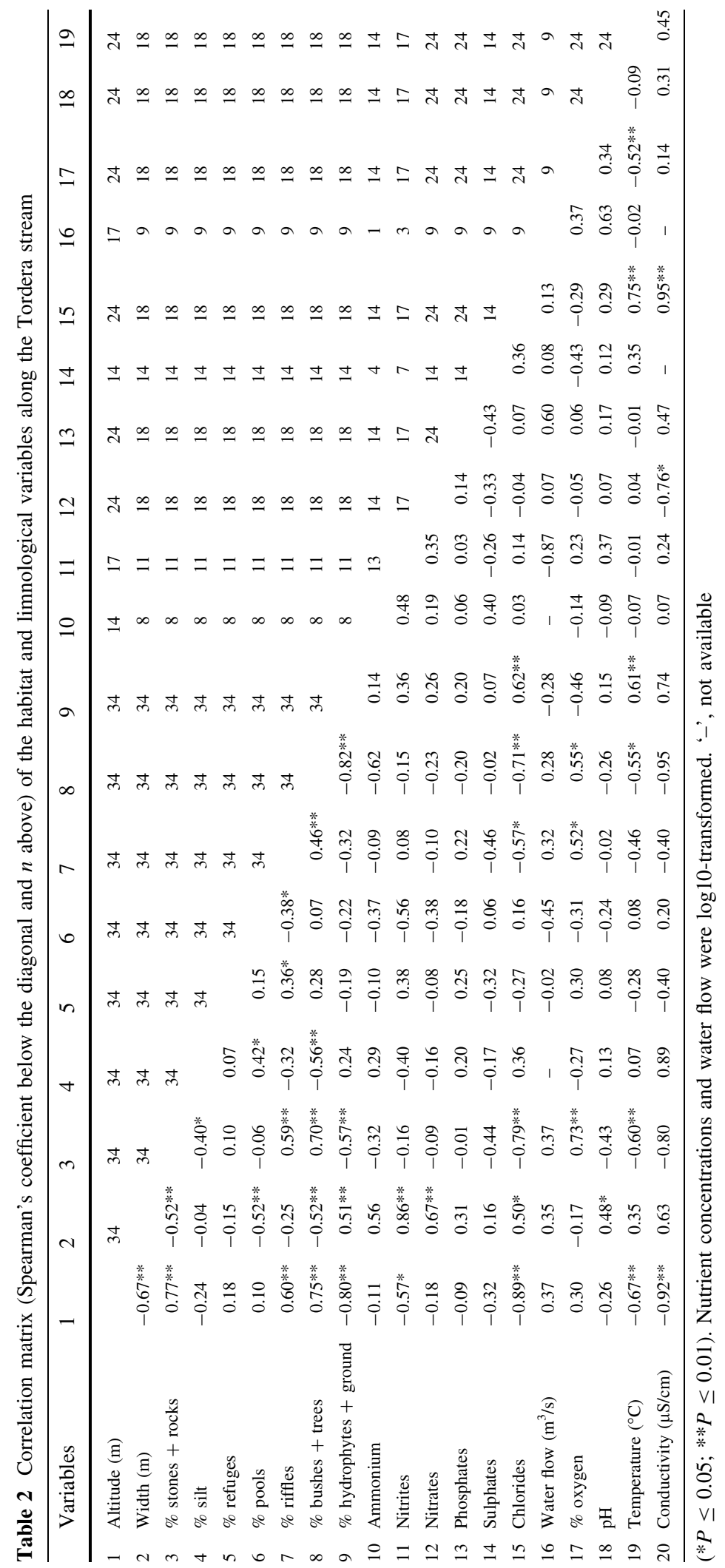



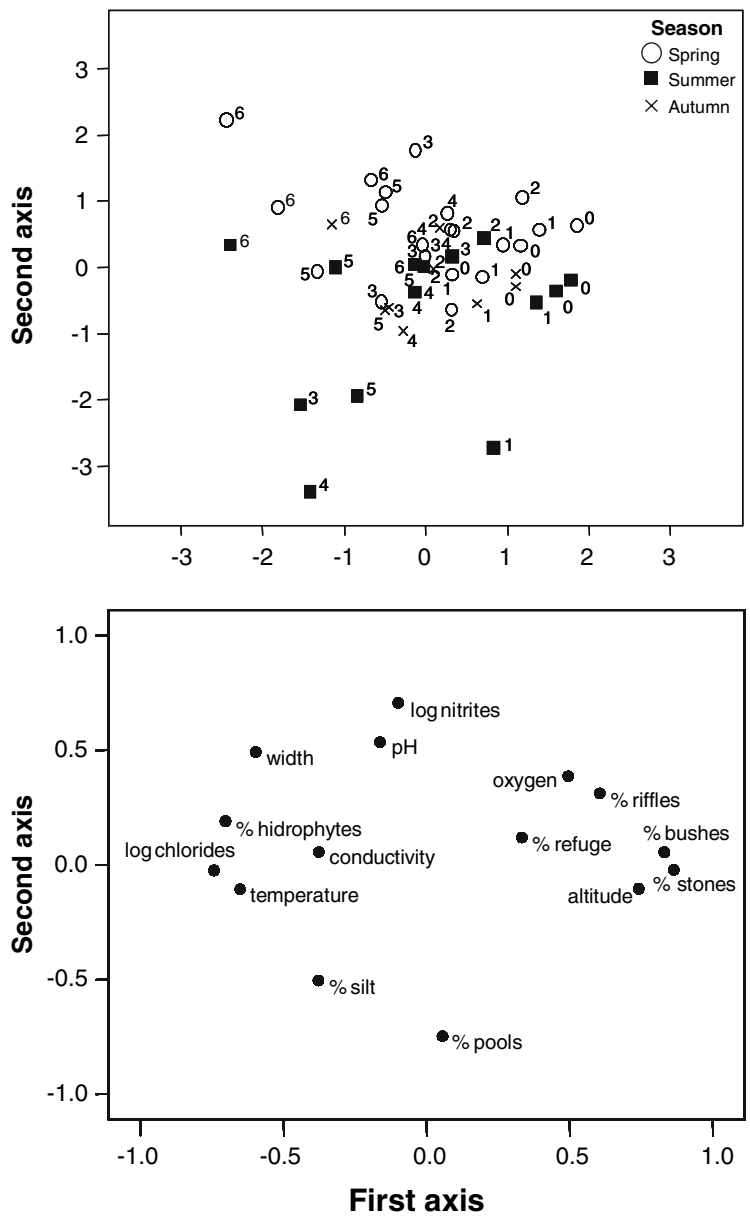

Fig. 2 Principal component analyses of the environmental variables in Tordera streams. Top: sample scores by season and sampling site; the numbers correspond to the sampling site in Fig. 1. Bottom: factor loadings of the environmental variables

explained $79.1 \%$ of the variation $(70.6 \%$ and $8.5 \%$, respectively) and showed that IBICAT and IH vs. ISQA were at two extremes of a gradient of indices (Fig. 5). Tordera stream was mainly responsible for these contrasting correlations: it had excellent water quality according to ISQA (physicochemical index) but poor according to IBMWP (macroinvertebrate index), hence displaying the lowest correlation between these two indices (Fig. 6). Similarly, the correlation between IBICAT and IBMWP in Tordera stream was the lowest and not significant (Fig. 6), because upper reaches had the best ecological status according to macroinvertebrates but rather the worst according to fish (owing to the dominance of brown trout, considered as introduced by IBICAT).

\section{Discussion}

Fish assemblage in Tordera stream

In our study, the fish assemblage of the most upstream sampling site was dominated by salmonids, whereas the rest of sampling sites were numerically dominated by Mediterranean barbel and chub. Overall, fish richness increased from headwaters to downstream (Fig. 3) as usual and expected in undisturbed systems (Schlosser, 1990; Pires et al., 1999; Magalhães et al., 2002), but this increase was partly due to exotic species such as common carp, mosquitofish, largemouth bass and pumpkinseed (Table 3). These species were mainly concentrated in site 5, owing to the presence of a small man-made physical barrier that enhanced the presence of more limnophilic species such as common carp, largemouth bass and pumpkinseed.

Fish abundance also increased along the longitudinal gradient, as previously reported in Mediterranean streams (Bravo et al., 2001; Magalhães et al., 2002), except in the last sampling site where fish abundance decreased (Fig. 3) because flow became lower than in upstream sampling sites, particularly in the very dry summer of 2001. This anomaly of the last sampling site was at least in part caused by heavy water abstraction that intensified the drought periods.

Fish metrics and biotic indices

The relationships among eight water quality and biotic indices for four Catalan river basins (Table 5, Fig. 5) indicated that most of them were positively correlated, particularly macroinvertebrate-based indices (FBILL, BMWPC, IBMWP, and IASPT), but also the riparian vegetation index (QBR). The diatombased index (IPS) was correlated with FBILL but less so with QBR; this is probably to be expected since QBR is rather a hydromorphological index whereas IPS and FBILL are more related to water quality. The least correlated indices were IBICAT, IH, and ISQA, that behaved quite differently, particularly in the Tordera stream (Fig. 6). For these three indices some of the correlations were not significant and more importantly were generally low (explaining only about $15 \%$ of variation). Although the water quality 
Table 3 Fish species captured in the Tordera stream

\begin{tabular}{llllrrrr}
\hline Common name & Scientific name & Family & $\begin{array}{l}\text { Native to } \\
\text { Catalonia }\end{array}$ & $\begin{array}{l}\text { Mean length } \\
(\mathrm{mm})\end{array}$ & $\begin{array}{l}\text { Length range } \\
(\mathrm{mm})\end{array}$ & $\begin{array}{c}n \\
\text { Stretch } \\
\text { presence }\end{array}$ \\
\hline Eel & Anguilla anguilla & Anguillidae & Yes & 153.7 & $25-900$ & 490 & $0,3-6$ \\
Mediterranean barbel & Barbus meridionalis & Cyprinidae & Yes & 73.8 & $22-236$ & 1513 & $1-6$ \\
Chub & Squalius cephalus & Cyprinidae & Yes & 101.5 & $20-360$ & 859 & $1-6$ \\
Common carp & Cyprinus carpio & Cyprinidae & No & 245.0 & $50-600$ & 20 & $4-5$ \\
Mosquitofish & Gambusia holbrooki & Poeciliidae & No & 19.8 & $7-42$ & 63 & $3,5-6$ \\
Pumpkinseed sunfish & Lepomis gibbosus & Centrarchidae & No & 85.0 & 85 & 1 & 5 \\
Largemouth bass & Micropterus salmoides & Centrarchidae & No & 120.2 & $110-130$ & 4 & 5 \\
Mullet & Liza sp. & Mugilidae & Yes & 109.1 & $66-130$ & 8 & 5 \\
Brown trout & Salmo trutta & Salmonidae & Yes & 139.4 & $32-300$ & 214 & $0-4$ \\
Rainbow trout & Oncorhynchus mykiss & Salmonidae & No & 273.5 & $250-326$ & 4 & 0,3 \\
Minnow & Phoxinus phoxinus & Cyprinidae & Yes & 51.1 & $33-70$ & 34 & 1,3 \\
\hline
\end{tabular}

Length is fork length except for eel (total length). Stretch presence reports the sampling sites (see Table 1 for codes) where the species was detected

index (ISQA) has been routinely used by the Catalan Government, it is a very simple index that only considers a few physical and chemical properties of water. Our results suggest that ISQA is the less sensitive index, because it does not capture disturbances that emerge with the other indices. In particular, the relationship of IBMWP with ISQA was particularly poor for Tordera stream (Fig. 6) probably because this stream is more affected by water abstraction (relatively low IBMWP values) and less by organic or inorganic pollution (high ISQA values). Oberdorff \& Hughes (1992) found similar discrepancies between physico-chemical and biological evaluations of water bodies' quality. Overall, our results suggest that: (i) although most indices are correlated, they reflect different quality aspects, (ii) that ISQA should not be generally used, (iii) that IBICAT and IH are among the least correlated and need more evaluation, and (iv) water abstraction, an important problem in Mediterranean streams, is not well captured by most indices.

Similarly, IBICAT was the least correlated among the biotic indices (Table 5, Fig. 5), particularly for the Tordera stream where it clearly had no relationship with macroinvertebrate indices like IBMWP (Fig. 6). Although some differences among biotic indices are to be expected because different taxa show contrasting responses to different perturbations (e.g., water abstraction, pollution, habitat alteration) or environmental gradients (Paavola et al., 2003), we believe that such a poor correlation for Tordera stream should not be observed and is related to the status of brown trout.

The status of brown trout in Tordera basin

The brown trout is considered in IBICAT (Sostoa et al., 2003; ACA, 2006) as introduced in the Tordera basin, probably following previous local accounts (Baucells et al., 1998; Ordeix Rigó et al., 1999). Whether brown trout is treated as native or introduced to this river basin, has profound effects on the results of fish metrics because of its dominance in the upper reaches (Fig. 3). In clear contrast to when trout is considered as native, percentage of native fish species and percentage of native fish individuals (some of the main metrics of IBICAT and other fish indices) are negatively correlated to other biotic indices when fish metrics are computed with trout as introduced (Table 4), thus explaining at least in part the low correlation of IBICAT with other biotic indices like IBMWP (Fig. 6).

The basis for considering brown trout as introduced to Tordera basin was: (i) that at present the Tordera population is genetically very similar to those of hatchery origin (Aparicio et al., 2005), which are genetically and morphologically distinct to native stocks but have been stocked throughout the Iberian Peninsula to satisfy angling demands 

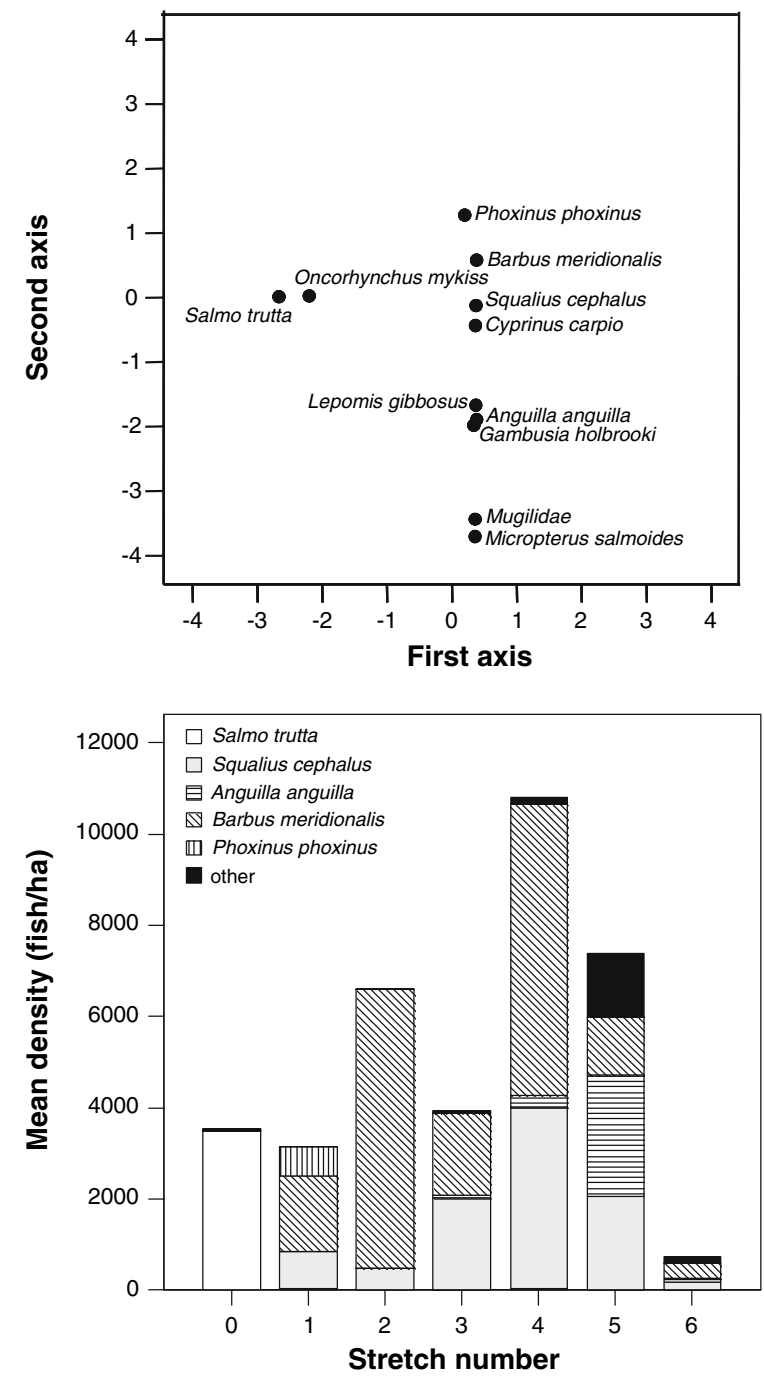

Fig. 3 Fish assemblages in the Tordera stream. Top: Species scores on the first two axes of the correspondence analysis. Bottom: mean abundance by fish species and sampling site. Stretch number corresponds to the sampling site in Table 1

(Aparicio et al., 2005; Almodóvar et al., 2006); and (ii) it is a low altitude population that was probably introduced long ago (A. de Sostoa, pers. comm.). Although the Tordera population had $100 \%$ of individuals of foreign origin according to a single gene locus, Aparicio et al. (2005) suggest two possibilities: it might be either a naturalized population of hatchery fish or a population where native fish have been almost completely removed by continuous introductions. Moreover, we just discovered a record of trout presence in Tordera stream (Montseny village) by 1845 (Madoz, 1845) and there is a small tributary in the basin named "Riera de les Truites" ("trout stream" in Catalan), an official toponym which is probably centuries old. The first salmonid hatchery in the Iberian Peninsula (Monasterio de Piedra) was built in 1867 (Lizasoain, 1912) and it was not until the late nineteenth century that important trout stockings started (Lizasoain, 1912; Muñoz, 1988); the first documented introduction of brown trout in the (French) Pyrenean high-mountain lakes is from ca. 1860, although older introductions are likely (Miró, 2007). The brown trout (Salmo trutta) is the most widely distributed freshwater fish native to the Palearctic region, native across most of Europe, including the Iberian Peninsula, western Asia and part of North Africa owing to high dispersal potential of salmonids through the sea (Bernatchez, 2001). The Mediterranean populations of brown trout originated from the Mediterranean Sea region and colonized its tributaries during the Pleistocene (Bernatchez, 2001; Cortey et al., 2004). The trout is also native to the main river basin (Ter river) neighbouring the Tordera basin (ACA, 2006), which starts flowing in the Montseny mountains (maximum altitude $1706 \mathrm{~m}$ a.s.l. with $7^{\circ} \mathrm{C}$ of yearly average temperature, Peñuelas \& Boada, 2003), at ca. $1100 \mathrm{~m}$ of altitude and only $2 \mathrm{~km}$ apart from a Ter tributary. The upper critical water temperature of trout is $25-26^{\circ} \mathrm{C}$ (Klemetsen et al., 2003), well above the summer maxima of upper reaches of Tordera upstream (maximum mean temperature is $18.5^{\circ} \mathrm{C}$ ). Introduced species are a serious environmental problem (Clavero \& García-Berthou, 2005), should not be included for absolute richness metrics according to some authors (Karr et al., 1986; Scott \& Helfman, 2001) and could be a reliable indicator of poor river health (Kennard et al., 2005). However, judging whether a species is native or introduced to a certain region can be problematic. Paleoecological information is the only certain evidence of native status and historical records the only evidence of introduction, whereas other criteria (e.g. naturalization elsewhere, distribution type, genetics) are also helpful but less sure (Pyšek et al., 2004). Since we are not aware of neither paleoecological information or introduction records before 1845 in the basin, the trout status in this basin is uncertain. Genetics points to introduction or almost complete introgression but biogeography, historical records, and ecology points to possible native status in historical times. Given that trout is an 
Table 4 Correlation matrix (Spearman's coefficient below the diagonal and $n$ above) of several fish metrics and water quality and biotic indices in the Tordera stream

\begin{tabular}{|c|c|c|c|c|c|c|c|c|c|c|c|c|c|}
\hline & Variables & 1 & 2 & 3 & 4 & 5 & 6 & 7 & 8 & 9 & 10 & 11 & 12 \\
\hline 1 & $\%$ fish with anomalies & & 26 & 26 & 26 & 26 & 26 & 26 & 26 & 26 & 14 & 17 & 5 \\
\hline 2 & Native richness & $0.40 *$ & & 34 & 34 & 33 & 33 & 33 & 33 & 34 & 18 & 22 & 7 \\
\hline 3 & Exotic richness & 0.34 & $0.61 * *$ & & 34 & 33 & 33 & 33 & 33 & 34 & 18 & 22 & 7 \\
\hline 4 & Native richness $^{\mathrm{a}}$ & 0.28 & $0.97 * *$ & $0.60 * *$ & & 33 & 33 & 33 & 33 & 34 & 18 & 22 & 7 \\
\hline 5 & $\%$ native fish species & -0.24 & $-0.41 *$ & $-0.96^{* *}$ & $-0.42 *$ & & 33 & 33 & 33 & 33 & 17 & 21 & 6 \\
\hline 6 & $\begin{array}{r}\% \text { native fish } \\
\text { individuals }\end{array}$ & -0.10 & $-0.44 * *$ & $-0.89 * *$ & $-0.44 * *$ & $0.90 * *$ & & 33 & 33 & 33 & 17 & 21 & 6 \\
\hline 7 & $\%$ native fish species ${ }^{\mathrm{a}}$ & -0.38 & 0.12 & -0.32 & 0.26 & 0.34 & 0.34 & & 33 & 33 & 17 & 21 & 6 \\
\hline 8 & $\begin{array}{l}\text { \% native fish } \\
\text { individuals }^{\mathrm{a}}\end{array}$ & -0.25 & 0.16 & -0.32 & 0.29 & $0.35 *$ & $0.44 *$ & $0.93 *$ & & 33 & 17 & 21 & 6 \\
\hline 9 & Total fish density & 0.30 & $0.45 * *$ & 0.31 & $0.39 *$ & -0.19 & -0.20 & -0.16 & -0.15 & & 18 & 22 & 7 \\
\hline 10 & FBILL & -0.25 & -0.31 & -0.30 & -0.43 & 0.34 & 0.42 & -0.23 & -0.20 & -0.08 & & 16 & 7 \\
\hline 11 & IPS & -0.40 & -0.32 & -0.31 & -0.37 & 0.34 & 0.23 & $-0.46^{*}$ & -0.41 & -0.04 & $0.72 * *$ & & 7 \\
\hline 12 & QBR & 0.11 & 0.22 & -0.49 & 0.04 & $0.83^{*}$ & $0.85^{*}$ & 0.00 & 0.03 & 0.43 & 0.64 & 0.36 & \\
\hline
\end{tabular}

a $=$ with brown trout considered as introduced

$* P \leq 0.05 ; * * P \leq 0.01$

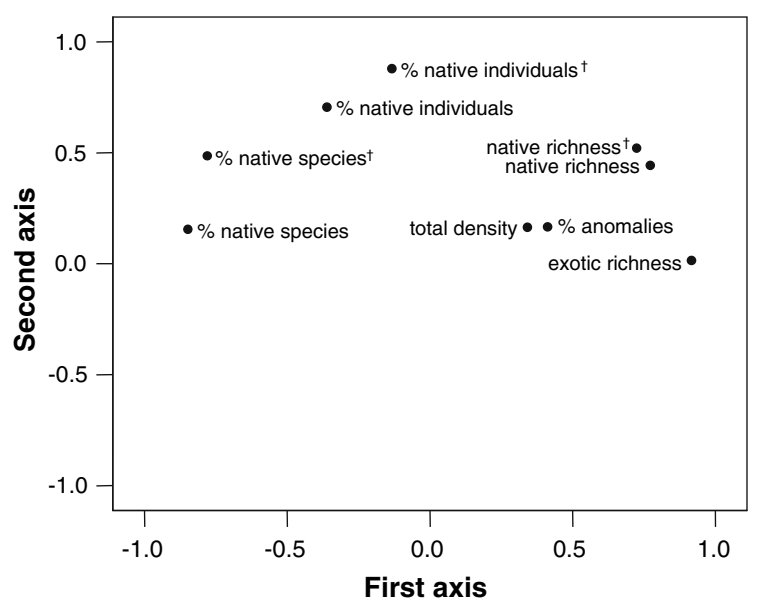

Fig. 4 Principal component analyses of the fish metrics in Tordera stream (the two axes respectively explained $41.1 \%$ and $22.8 \%$, ,.$\dagger$, with brown trout considered as introduced intolerant species, sensitive to pollution and habitat degradation, we suggest that it might be safe to treat it as native in this particular case. At the very least, it should not be treated as introduced but as uncertain (i.e. considered not native nor introduced), to compute metrics such as percentage of native species or of native individuals, unless historical introduction records are found.

Even if the introduced status of brown trout was confirmed, how to deal with this fact in fish indices can be contentious. First, because brown trout is dominant and often the only species in the upper stretches, only penalising its presence or abundance would result in lower values of the index in these upper reaches, which generally have much better habitat and water quality than downstream areas (and thus negative correlation with other biotic indices).
Table 5 Correlation matrix (Spearman's coefficient below the diagonal and $n$ above) of several water quality and biotic indices in four Catalan river basins (Besós, Foix, Llobregat and

Tordera) from 2001 to 2002 $\left.{ }^{*}, P \leq 0.05 ; * *, P \leq 0.01\right)$

$* P \leq 0.05 ; * * P \leq 0.01)$

\begin{tabular}{llllllllll}
\hline & Indices & 1 & 2 & 3 & 4 & 5 & 6 & 7 & 8 \\
\hline 1 & FBILL & & 145 & 145 & 145 & 73 & 56 & 23 & 35 \\
2 & IBMWP & $0.95^{* *}$ & & 146 & 146 & 73 & 57 & 23 & 36 \\
3 & IASPT & $0.88^{* *}$ & $0.90^{* *}$ & & 146 & 73 & 57 & 23 & 36 \\
4 & QBR & $0.76^{* *}$ & $0.77^{* *}$ & $0.71^{* *}$ & & 73 & 57 & 23 & 39 \\
5 & IH & $0.60^{* *}$ & $0.61 * *$ & $0.54 * *$ & $0.57 * *$ & & 29 & 11 & 31 \\
6 & ISQA & $0.66^{* *}$ & $0.58^{* *}$ & $0.63^{* *}$ & $0.57 * *$ & $0.39 *$ & & 22 & 18 \\
7 & BMWPC & $0.83^{* *}$ & $0.83^{* *}$ & $0.80^{* *}$ & $0.72 * *$ & $0.75^{* *}$ & $0.79 * *$ & & 4 \\
8 & IBICAT & $0.73^{* *}$ & $0.63^{* *}$ & $0.67 * *$ & $0.63 * *$ & $0.44 *$ & 0.34 & 0.80 & \\
\hline
\end{tabular}




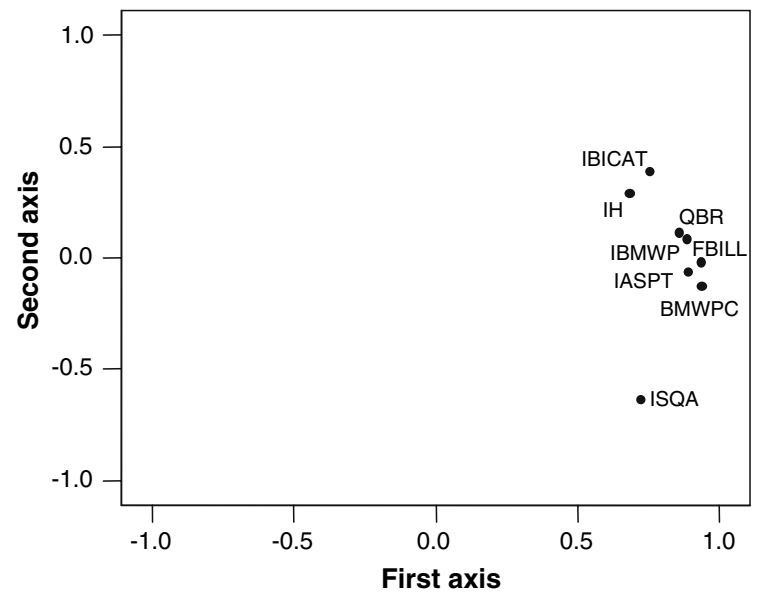

Fig. 5 Principal component analyses of eight indices for four Catalan river basins (Besós, Foix, Llobregat and Tordera) during 2001 and 2002. The two PCA axes respectively explained $70.57 \%$ and $8.54 \%$ of the variation

An acute pollution problem or another severe disturbance that killed the trout population would result in an improvement of the index. Although this might be adequate if the objective is to measure taxonomic or genetic integrity, it might not be if the objective is a more general measure of ecological functioning. Second, one might also argue that the ecological impact of such an introduced population of trout is very old and difficult to ascertain, whereas the ability of such an intolerant species to sustain a population is an indicator of good ecosystem health and condition rather than biological integrity. Moyle \& Marchetti (1999) discuss a similar situation with introduced salmonids in Californian montane streams. Thus, the use of the introduced status of trout would depend on carefully defining what we want to measure with the fish index. Further problems to be solved are: (i) that within a river basin, trout might be native to a certain zone but translocated to other streams in the basin; (ii) the cases of introgressed populations, formed of partially native and partially introduced genes; and (iii) sites heavily stocked for angling purposes.

At the very least we recommend: (i) for headwater sites (trout zone) or sites with low richness, to assess metrics based on age or size structure, fish individual state, or other taxa such as amphibians (Moyle \& Marchetti, 1999) to compensate for the low fish richness. Otherwise, only considering richness and compositional (e.g., \% intolerant) metrics mostly evaluates trout abundance and is thus likely to result
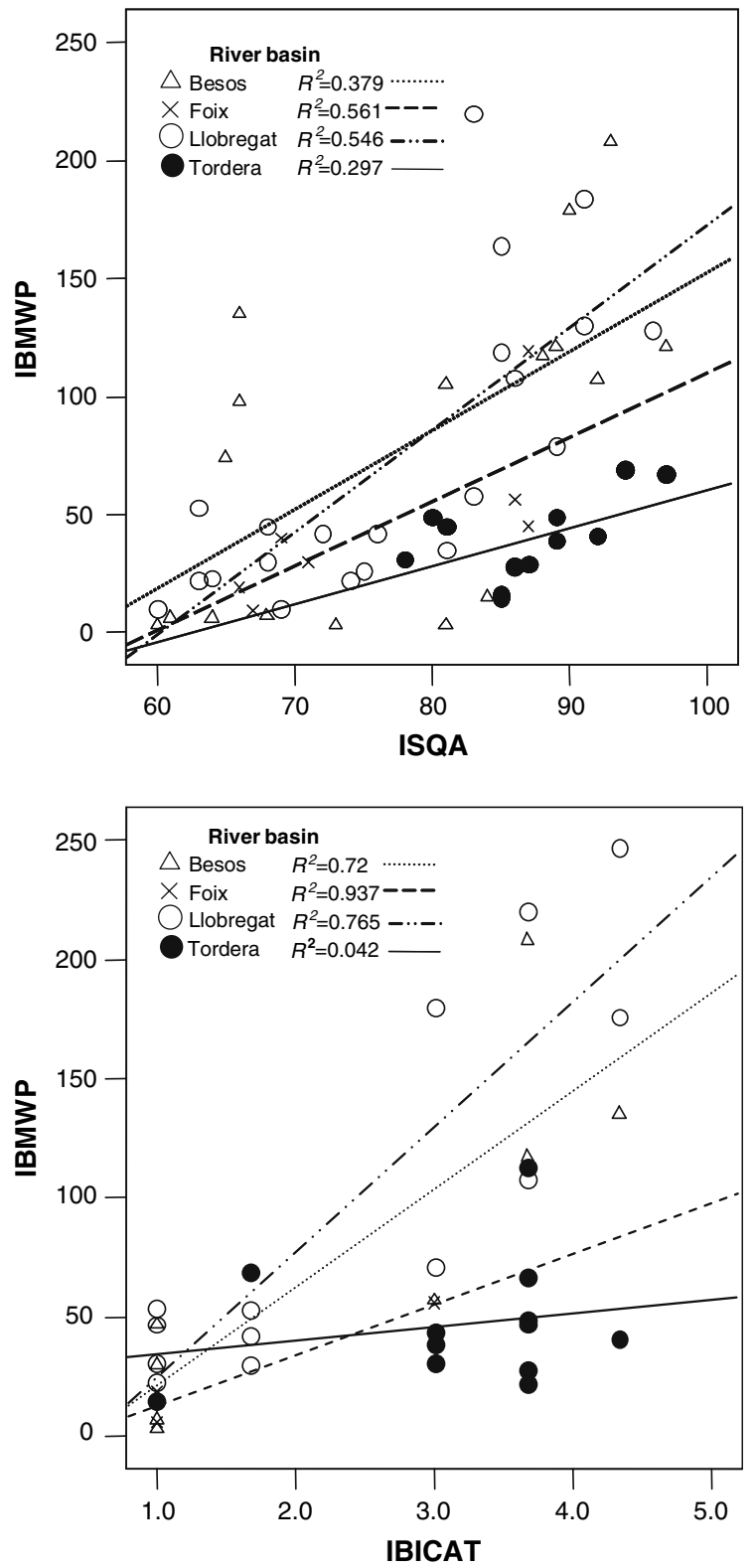

Fig. 6 Relationship of IBMWP (macroinvertebrate index) with ISQA (water quality index) and IBICAT (fish index) in four Catalan river basins (Besós, Foix, Llobregat and Tordera) during 2001 to 2002. Linear regression functions for the four basins are shown

in redundant metrics and actually analysing taxonomic composition rather than ecological structure, which is supposed to be the advantage of multimetric indices (Karr 1999); (ii) to consider, as in Moyle \& Marchetti (1999), metrics that penalize for the presence or abundance of introduced fishes (to 
measure historic biotic integrity) but at the same time metrics that profit from their indicator value; and (iii) not to propose the use of fish indices for these zones of low richness, unless several nonredundant metrics are identified. The minimum number of metrics adequate for such an index and its relationship with the number of species present in the ecosystem should also be investigated. Miller et al. (1988) suggest that although an IBI with less than 12 metrics may work, it may be less responsive to a broad spectrum of degradation.

The uncertainties with the native status of brown trout are likely to appear in many other European river basins and sites. For instance, trout has also been considered as introduced in another Catalan river basin (Fluvià) (ACA, 2006; Sostoa et al., 2003) because of frequent stocking in that river; however, bone remains of brown trout in Palaeolithic sediments of a cave (Ermitons) next to a Fluvià tributary have been previously identified (Juan-Muns, 1982; Estévez, 1987). Mediterranean downstream sites are less likely to be affected because the increasing number of species downstream will diminish the effects of incorrect native status on index performance. Our study exemplifies the need of careful, basin-specific assessment of native/introduced status in the development of fish metrics.

Acknowledgements We thank J. L. García-Marín and A. de Sostoa for discussion and two anonymous reviewers for comments that greatly improved an early version of the manuscript. This study was financially supported by the Catalan Water Agency (ACA), Government of Catalonia ("Observatori de la Tordera" to Martí Boada), the Spanish Ministry of Education (CGL2006-11652-C02-01/BOS) and the Government of Catalonia (Catalan Government Distinction Award for University Research 2004 to EGB). LB held a doctoral fellowship from the University of Girona. We are also grateful to the stimulating environment of the "Observatori de la Tordera" project.

\section{References}

ACA (Agència Catalana de l'Aigua), 2006. Protocol d'avaluació de la qualitat biològica dels rius. Generalitat de Catalunya, Barcelona: 89 pp. [available on-line at: http:// www.gencat.net/aca/documents/ca/directiva_marc/ manual_biologica_rius.pdf].

ACA (Agència Catalana de l'Aigua) (ed.), 2003. Anàlisi de la viabilitat i proposta d'indicadors fitobentònics de la qualitat de l'aigua per als cursos fluvials de Catalunya. Generalitat de Catalunya, Barcelona: 89 pp. 113 p. [http:// www.gencat.net/aca/documents/ca/directiva_marc/ informe_final_diatomees.pdf].

Alba-Tercedor, J. \& A. Sánchez-Ortega, 1988. Un método rápido y simple para evaluar la calidad biológica de las aguas corrientes basado en el de Helawell (1978). Limnetica 4: 51-56.

Alba-Tercedor, J., P. Jáimez-Cuéllar, M. Álvarez, J. Avilés, N. Bonada, J. Casas, A. Mellado, M. Ortega, I. Pardo, N. Prat, M. Rieradevall, S. Robles, C. Elisa Sáinz-Cantero, A. Sánchez-Ortega, M. L. Suárez, M. Toro, M. R. VidalAbarca, S. Vivas \& C. Zamora-Muñoz, 2002. Caracterización del estado ecológico de ríos mediterráneos ibéricos mediante el índice IBMWP (antes BMWP'). Limnetica 21: 175-185.

Almodóvar, A., G. G. Nicola, B. Elvira \& J. L. García-Marín, 2006. Introgression variability among Iberian brown trout evolutionary significant units: the influence of local management and environmental features. Freshwater Biology 51: 1175.

Aparicio, E., M. J. Vargas, J. M. Olmo \& A. Sostoa, 2000. Decline of native freshwater fishes in a Mediterranean watershed on the Iberian Peninsula: a quantitative assessment. Environmental Biology of Fishes 59: 11-19.

Aparicio, E., E. García-Berthou, R. M. Araguas, P. Martínez \& J. L. García-Marín, 2005. Body pigmentation pattern to assess introgression by hatchery stocks in native Salmo trutta from Mediterranean streams. Journal of Fish Biology 67: 931-949.

Baucells, J., J. Camprodon \& J. Ordeix, 1998. La fauna vertebrada d'Osona. Atles dels peixos amfibis, rèptils, ocells i mamífers actuals i extingits recentment de la Plana de Vic, el Pre-pirineu, el Collsacabra, les Guilleries, el Montseny i el Lluçanès. Lynx edicions, Barcelona, 246 pp.

Benito, G. \& M. A. Puig, 1999. BMWPC un índice biológico para la calidad de las aguas adaptado a las características de los ríos catalanes. Tecnología del Agua 191: 43-56.

Bernatchez, L., 2001. The evolutionary history of brown trout (Salmo trutta L.) inferred from phylogeographic, nested clade, and mismatch analyses of mitochondrial DNA variation. Evolution 55: 351-379.

Boada, M., L. Capdevila, M. Miralles, J. Jubany, J. Gomà, M. J. Vargas, E. Aparicio, D. Carrera, S. Sánchez, E. Badosa, T. Colomer, J. Mas, M. Ventura \& J. Viader, 2003. L'Observatori: estació de seguiment de la biodiversitat de la conca de la Tordera. Institut de Ciència i Tecnologia Ambientals, Barcelona, 420 pp.

Bonada, N., C. Zamora-Muñoz, M. Rieradevall \& N. Prat, 2004. Ecological profiles of caddisfly larvae in Mediterranean streams: implications for bioassessment methods. Environmental Pollution 132: 509-521.

Bravo, R., M. C. Soriguer, N. Villar \& J. A. Hernando, 2001. The dynamics of fish populations in the Palancar stream, a small tributary of the river Guadalquivir, Spain. Acta Oecologica 22: 9-20.

Cemagref, 1982. Étude des méthodes biologiques d'appréciation quantitative de la qualité des eaux. Rapport Division qualité des eaux Cemagef Lyon. Agence de l'Eau RhôneMéditérannée-Corse, Lyon, 218 pp.

Clavero, M. \& E. García-Berthou, 2005. Invasive species are a leading cause of animal extinctions. Trends in Ecology and Evolution 20: 110. 
Cortey, M., C. Pla \& J. L. García-Marin, 2004. Historical biogeography of Mediterranean trout. Molecular Phylogenetics and Evolution 33: 831-844.

Damásio, J. B., C. Barata, A. Munné, A. Ginebreda, H.Guasch, S. Sabater, J. Caixach \& C. Porte, 2007. Comparing the response of biochemical indicators (biomarkers) and biological indices to diagnose the ecological impact of an oil spillage in a Mediterranean river (NE Catalunya, Spain). Chemosphere 66: 1206-1216.

Doadrio, I., B. Elvira \& Y. Bernat, 1991. Peces continentales españoles. Inventario y clasificación de zonas fluviales. In ICONA (eds), Madrid, $221 \mathrm{pp.}$

Doménech, R., A. Gaudes, J. C. López-Doval, H. Salvadó \& I. Muñoz, 2006. Effects of short-term nutrient addition on microfauna density in a Mediterranean stream. Hydrobiologia 568: 207-215.

Estévez, J., 1987. Dynamique des faunes préhistoriques au N-E de la péninsule Ibérique. Archaeozoologia 1: 197-218.

Hughes, R. M. \& T. Oberdorff, 1999. Applications of IBI concepts and metrics to waters outside the United States and Canada. In Simon, T. P. (ed.), Assessing the Sustainability and Biological Integrity of Water Resources Using Fish Communities. Boca Raton, Florida.

Juan-Muns, N., 1982. La ictiofauna de Catalunya en el paleolític. Revista de Girona 99: 127-130.

Karr, J. R., 1981. Assessment of biotic integrity using fish communities. Fisheries 6: 21-27.

Karr, J. R., 1999. Defining and measuring river health. Freshwater Biology 41: 221-234.

Karr J. R., K. D. Fausch, P. L. Angermeier, P. R. Yant \& I. J. Schlosser, 1986. Assessing Biological Integrity in Running Waters: A Method and its Rationale. Illinois Natural History Survey, Champaign, Illinois.

Kennard, M. J., A. H. Arthington, B. J. Pusey \& B. D. Harch, 2005. Are alien fish a reliable indicator of river health? Freshwater Biology 50: 174-193.

Klemetsen, A., P. A. Amundsen, J. B. Dempson, B. Jonsson, N. Jonsson, M. F. O'Connell \& E. Mortensen, 2003. Atlantic salmon Salmo salar L., brown trout Salmo trutta L. and arctic charr Salvelinus alpinus (L.): a review of aspects of their life histories. Ecology of Freshwater Fish 12: 1-59.

Lizasoain, J., 1912. Resumen de los trabajos ejecutados por la administración pública para la repoblación piscícola. Cuerpo de Montes, Madrid, 87 pp.

Madoz, P., 1845. Diccionario geográfico-estadístico-histórico de España y sus posesiones de ultramar. In Curial (eds), Barcelona, $150 \mathrm{pp}$.

Magalhães, M. F., D. C. Batalha \& M. J. Collares-Pereira, 2002. Gradients in stream fish assemblages across a Mediterranean landscape: contributions of environmental factors and spatial structure. Freshwater Biology 47: 1015-1031.

Miller, D. L., P. M. Leonard, R. M. Hughes, J. R. Karr, P. B. Moyle, L. H. Schrader, B. A. Thompson, R. A. Daniels, K. D. Fausch, G. A. FitzHugh, J. R. Gammon, D. B. Halliwell, P. L. Angermeier \& D. J. Orth, 1988. Regional applications of an index of biotic integrity for use in water resource management. Fisheries 13: 12-20.

Miró, A., 2007. La introducció del peixos als estanys pirinencs: procés històric i distribució actual a Catalunya i Aragó. Unpublished M.Sc. thesis, Barcelona, 69 pp.
Moyle, P. B. \& M. P. Marchetti, 1999. Applications of indices of biotic integrity to California streams and watersheds. In Simon, T. P. (ed.), Assessing the Sustainability and Biological Integrity of Water Resources Using Fish Communities. CRC Press, Boca Raton, Florida, 367-380.

Munné, A., N. Prat, C. Solà, N. Bonada \& M. Rieradevall, 2003. A simple field method for assessing the ecological quality of riparian habitat in rivers and streams: QBR index. Aquatic Conservation: Marine and Freshwater Ecosystems 13: 147-163.

Muñoz, G., 1988. Crónica piscícola continental hispana. In ICONA (eds), Madrid, 193 pp.

Oberdorff, T. \& R. M. Hughes, 1992. Modification of an index of biotic integrity based on fish assemblages to characterize rivers of the Seine basin, France. Hydrobiologia 228: $117-130$.

Oberdorff, T., D. Pont, B. Hugueny \& J. P. Porcher, 2002. Development and validation of a fish-based index for the assessment of rivers 'health' in France. Freshwater Biology 47: 1720-1735.

Ordeix Rigó, M. O., J. Maluquer-Margalef \& J. Camprodon Subirach, 1999. Estudi de la distribució de la fauna amfíbia i aquàtica de les rieres del Parc Natural del Montseny, III i IV Trobades d'Estudiosos del Montseny. Monografies 27: 215-227.

Ortiz, J. D., E. Martí \& M. Puig, 2006. Influences of a point source on the microhabitat distribution of stream benthic macroinvertebrates. Archive Hydrobiology 165: 469-491.

Paavola, R., T. Muotka, R. Virtanen, J. Heino \& P. Kreivi, 2003. Are biological classifications of headwater streams concordant across multiple taxonomic groups? Freshwater Biology 48: 1912-1923.

Pardo, I., M. Álvarez, J. Casas, J. L. Moreno, S. Vivas, N. Bonada, J. Alba-Tercedor, P. Jáimez-Cuéllar, G. Moyà, N. Prat, S. Robles, M. L. Suárez, M. Toro \& M. R. VidalAbarca, 2002. El hábitat de los ríos mediterráneos. Diseño de un índice de diversidad de hábitat. Limnetica 21: 115133.

Peñuelas, J. \& M. Boada, 2003. A global change-induced biome shift in the Montseny mountains (NE Spain). Global Change Biology 9: 131-140.

Pires, A. M., I. G. Cowx \& M. M. Coelho, 1999. Seasonal changes in fish community structure of intermittent streams in the middle reaches of the Guadiana basin, Portugal. Journal of Fish Biology 54: 235-249.

Prat, N., G. González \& X. Mollet, 1986. Comparación crítica de dos índices de calidad del agua: ISQA y BILL. Tecnología del Agua 31: 33-49.

Prat, N., A. Munné, C. Solà, M. Rieradevall, N. Bonada \& G. Chacon, 1999. La qualitat ecològica del Besòs i el Llobregat. Diputació de Barcelona, Barcelona, 154 pp.

Prat, N., A. Munné, C. Solà, M. Rieradevall, N. Bonada \& G. Chacon, 2000. La qualitat ecològica del Llobregat, el Besòs, el Foix i la Tordera. Diputació de Barcelona, Barcelona, 162 pp.

Prat, N., A. Munné, C. Solà, R. Casanovas-Berenguer, M. VilaEscalé, N. Bonada, J. Jubany, M. Miralles, M. Plans \& M. Rieradevall, 2002. La qualitat ecològica del Llobregat, el Besòs, el Foix i la Tordera. Diputació de Barcelona, Barcelona, 163 pp. 
Pont, D., B. Hugueny, U. Beier, D. Goffaux, A. Melcher, R. Noble, C. Rogers, N. Roset \& S. Schmutz, 2006. Assessing river biotic condition at a continental scale: a European approach using functional metrics and fish assemblages. Journal of Applied Ecology 43: 70-80.

Pyšek, P., D. M. Richardson, M. Rejmánek, G. Webster, M. Williamson \& J. Kirschner, 2004. Alien plants in checklists and floras: towards better communication between taxonomists and ecologists. Taxon 53: 131-143.

Queralt, R., 1982. La calidad de las aguas en los ríos. Tecnología del agua 4: 49-57.

Reyjol, Y., B. Hugueny, D. Pont, P. G. Bianco, U. Beier, N. Caiola, F. Casals, I. Cowx, A. Economou \& T. Ferreira, 2007. Patterns in species richness and endemism of European freshwater fish. Global Ecology and Biogeography $16: 65-75$.

Romaní, A. M., A. Giorgi, V. Acuña \& S. Sabater, 2004. The influence of substratum type and nutrient supply on biofilm organic matter utilization in streams. Limnology and Oceanography 49: 1713-1721.

Sabater, S., 2000. Diatom communities as indicators of environmental stress in the Guadiamar River, S-W. Spain, following a major mine tailings spill. Journal of Applied Phycology 12: 113-124.

Schlosser, I. J., 1990. Environmental variation, life history attributes, and community structure in stream fishes: implications for environmental management and assessment. Environmental Management 14: 621-628.

Scott, M. C. \& G. S. Helfman, 2001. Native invasions, homogenization, and the mismeasure of integrity of fish assemblages. Fisheries 26: 6-15.

Seber, G. A. F., 1982. The Estimation of Animal Abundance and Related Parameters. Blackburn Press, Caldwell, New Jersey.

Sostoa, A., N. Caiola, D. Vinyoles, S. Sánchez \& C. Franch, 2003. Development of a biotic integrity index (IBICAT) based on the use of fish as indicators of the environmental quality of the rivers of Catalonia. (In Catalan). Report to the Catalan Water Agency, Barcelona. [available on-line at: http://www.gencat.net/aca/en//planificacio/directiva/ treballs.jsp\#C].

ter Braak, C. J. F., 1987. The analysis of vegetation-environment relationships by canonical correspondence analysis. Vegetation 69: 69-77. 